\title{
The Influence of the Empowerment of the Elderly Group on Independence of Activities Daily Living in Arjuna Village Bandung
}

\author{
Ai Rokhayati, Ahmad Husni, Lia Melianingsih \\ Politeknik Kesehatan Bandung, Bandung, Indonesia \\ Email: airokhayati20@gmail.com, achmadhusni1965@gmail.com, latifa_dinarku55@yahoo.co.id
}

How to cite this paper: Rokhayati, A., Husni, A. and Melianingsih, L. (2019) The Influence of the Empowerment of the Elderly Group on Independence of Activities Daily Living in Arjuna Village Bandung. Open Journal of Nursing, 9, 925-934. https://doi.org/10.4236/ojn.2019.98069

Received: July 9, 2019

Accepted: August 26, 2019

Published: August 29, 2019

Copyright ( 2019 by author(s) and Scientific Research Publishing Inc. This work is licensed under the Creative Commons Attribution International License (CC BY 4.0).

http://creativecommons.org/licenses/by/4.0/

\begin{abstract}
The increasing number of the elderly in Indonesia as a result of the success of development has led to increasing problems in the elderly group whose natural life journey will experience an old age with all its limitations, especially in the health problems of the elderly who suffer from disabilities compared to younger people. The situation is also added that the elderly usually suffer from a variety of physiological disorders that are chronic, and biological aspect, psychological aspect, socio economic aspect will experience setback. The empowerment of elderly group is an effort to give power or strength so that elderly have independence, especially in aspects of intellectual ability, and aspects Physical, the empowerment of the elderly is done by improving ability through education. This study aims to analyze the influence of empowerment of the elderly group through health education on the independence of Activitiey Daily Living (ADL). The research design used quasi-experiment with the approach of pre post test group design without comparison (control), while the data analysis used t-test. The results of the study before being carried out empowerment through health education on the independence of the average value of independence were 9.9506 (SD 4.66074) and the result after being carried out empowerment through health education became 13.2716 (SD.4.61523) Research Results showed statistically significant influence on empowering the elderly group through health education to independence of the ADL with a p-value of 0.04 . Based on this, it is recommended that empowerment for the elderly should be determined in Posbindu activities. The effect of empowering the elderly group through more effective health education can influence the level of independence by providing a guidebook (module) which is equipped with interesting pictures about the procedures for fulfilling the needs of daily activities, finished providing educational guidebooks. The guidebook is given to the elderly group can be read repeatedly so that it affects the elderly memory in a longer period of time.
\end{abstract}




\section{Keywords}

Empowerment, Elderly Groups, Independence, Activities Daily Living

\section{Introduction}

Community empowerment is an effort or process to foster awareness, willingness and ability of the community to recognize, overcome, maintain, protect, and improve its own welfare. Community empowerment in the health sector is an effort or process to foster awareness of willingness and ability to maintain and improve health [1] [2] [3].

Elderly is someone who has reached the age of 60 years and above [4]. In Indonesia, the term for this age group is not yet standard, people have different names. There are those who use usia lanjut, lanjut usia, or jompo with pedigree words in English called the aged, the elders, or senior citizens [5].

The success of the government in national development has manifested positive results in various fields, namely economic progress, environmental improvement, advancement of science and technology, especially in the field of health, especially medicine and nursing, so as to improve the quality of population health and increase life expectancy. Throughout the world \pm 500 million elderly with an average age of 60 years and it is estimated that in 2025 will reach 1.2 billion. Meanwhile, according to the World Health Organization (WHO) that the elderly population in Indonesia in 2020 has reached $11.34 \%$ or recorded 28.8 million people, the population is only $6.9 \%$ which causes the largest number of the elderly population in the world (Central Statistics Agency (BPS)).

The increase in the elderly in Indonesia as a result of the success of development has led to increasing problems in the elderly group whose natural life journey will experience old age with all its limitations, especially in health problems. This is reinforced by the fact that older groups suffer more from diseases that cause disability compared to younger people. The situation is added by the fact that the elderly usually suffer from various types of physiological disorders that are chronic, and the biological aspect, the psychological aspect, socio economic aspect will experience setback [6].

This change will affect all aspects of life including their health. Therefore, the health of the elderly needs special attention while maintaining and improving so that they can live productively as long as possible.

In the elderly jobs that require power are no longer suitable, the elderly must turn to jobs that use the brain more than muscles, the ability to carry out daily activities (Activity Daily Living/ADL) has also decreased the daily activities that must be done by the elderly have five kinds including eating, bathing, dressing, mobility and dieting [6]. To meet the needs of the elderly, knowledge or cognitive needs and attitudes that can influence the behavior of the elderly in the independence of the needs of Activities Dailly Living (ADL). At this time, the el- 
derly have received very little attention in the middle of their families and communities, especially in fulfilling their daily activities/ADL.

The term ADL includes self-care (such as dressing, eating, and drinking, toileting, bathing, decorating, also preparing food, writing, managing money, etc.) and mobility (such as rolling in bed, waking up, and sitting, transferring/shifting from bed to chair or from one place to another) [7].

This is because the elderly have limited time, funds, energy and the ability to care for themselves while families cannot afford to help the elderly. So nursing homes or social care institutions can be their choices. Physical changes that occur in the elderly will certainly affect the independence of the elderly. Independence is freedom to act, not dependent on others, not affected by others and free to self-regulate one's activities or one's activities both individuals and groups from various health or diseases [8] [9]. The research conducted shows that of the 31 elderly respondents who are elderly who are classified as having dependency, there are 22 people and the independent ones are 9 people [10].

The number of elderly people with full dependence is more than the number of elderly who are independent. This indicates that the independence of the elderly in fulfilling Daily Living Activities in Tualango Village, Tilango District, Gorontalo Regency has not been fulfilled. On average, those who have dependence are due to physical limitations and a decrease in body function of the elderly who are no longer able to fully move.

Research results in line with the results of research conducted by Ediawati (2012) state that in Budi Mulia 01 Cipayung and Ciracas as many as 143 elderly have a level of independence and 3 elderly have low levels of independence. The high results of the analysis can be concluded that some of the respondents in Budi Mulia 01 Cipayung and 03 Ciracas PSTW have a high level of independence. However, the high level of independence in the elderly was caused by the condition of the orphanage with a social care background and the minimum number of care giver in the institution. The limited assistance received by the elderly from nursing staff forces the elderly to remain independent in fulfilling their daily activities (Activities Daily Living) [8] [9] [11].

\section{Methods}

\subsection{Study Design}

In this study, a design with one group pre test and post test design (quasy experiment) design was used to determine the level of independence in the Elderly Activities Daily Living (ADL) group through health education. This design seeks to reveal the influence of empowerment on Activities Daily Living (ADL) independence by involving groups of elderly people through health education [12].

\subsection{Place and Time of Research}

The location of this study was conducted in Posbindu, Arjuna Village, Cicendo District, Bandung. The time of this study begins in May to October 2017. 


\subsection{Population and Sample}

Population is an object or subject that is present in an area and fulfills certain requirements related to research problems. In this study, the population is the elderly group in Posbindu, Arjuna Village, Cicendo District, Bandung. Samples are elderly in Posbindu, Arjuna Village, 486 people. In order to obtain a representative sample, it must be sought so that each subject in the population has the same opportunity to be a sample element. The higher or greater variation of the population, the greater the sample required. The sampling technique in this study uses Simple Random Sampling technique. Simple random sampling is a method of sampling from members of the population by random use regardless of the strata (levels) in members and the population. This is done if members of the population are considered to be similar, or called homogeneous with the following formula [13] [14] [15]:

$$
n=\frac{Z^{2} \cdot P \cdot Q}{d^{2}}
$$

Information:

$Z=$ degree of trust

$p=$ proportion of target coverage of elderly visits to psobindu

$q=1-p$ (proportion of target coverage for elderly visits to psobindu)

$d=$ limit of error or absolute

precision If determined $z \alpha=5 \%(1.96), p=70 \% d=0.1$, then the application into the formula is:

$$
n=\frac{1.96^{2} \times 0.7 \times 0.3}{0.1^{2}}
$$

Thus the number of samples needed in this study is 80 people rounded up to 81 people, so that the conditions of respondents can be maintained homogeneity, then the sampling technique is done by means of ramdom sampling. Sampling is done by using purposive sampling, namely sampling based on a particular consideration made by the researcher himself, based on the characteristics or characteristics of the population that have been previously known [16].

The sample inclusion criteria are as follows:

1) Aged 60 years and above

2) Able to read and write

3) Don't suffer from hearing loss

4) Available to be a respondent

The sample exclusion criteria are as follows:

1) Elderly under the age of 60 years old

2) Elderly who can't read and write

3) Elderly who can't understand Indonesian language and can't communicate

4) Elderly who have a hearing loss

\subsection{Data Analysis}

1) Univariate Analysis 
Univariate analysis performed on each variable from the results of the study. In general, this analysis only results in the distribution and presentation of each variable [17]. The data is analyzed univariately. Univariate analysis is intended to determine the frequency distribution and proportion of the observed variables.

2) T-test analysis

Bivariate analysis was carried out by using a statistical test to test the difference in mean dependent i.e. by the dependent test t-test. This test is used to examine the influence between prior and after knowledge about independence with health education using the brainstorming method. The t-test is as follows.

$$
t=\frac{M d}{\sqrt{\frac{\sum X^{2} \cdot d}{N(N-1)}}}
$$

Information:

Md: Mean of difference between pretest and post test

$X d$ : Deviation of each subject

$t N$ : Subjects in the sample

d.b: Specified by $N-1$

\section{Results}

The result of the study and a discussion about the influence of the empowerment of the elderly group on the independence of ADL in Arjuna Village Bandung.

With a sample size of 81 people who were intervened. The sample age of 60 years - 85 years consisted of 10 men and 71 women. There was no control group in this study. The sample consisted of elderly people with male and female gender with an age range of $60-85$ years.

Table 1 explains that before the empowerment of the elderly group through health education a small proportion of respondents (4.9\%) experienced total dependence, almost all respondents (84.0\%) experienced partial dependence, and a small proportion of respondents (11.1\%) independent. After empowerment in the elderly group through ADL health education, there were differences, the percentage of independent elderly is (17.3\%), while almost all of the elderly are partially dependent (77.8\%), a small proportion (4.9\%) are total dependence.

Table 2 shows the average independence before empowering the elderly group through health education $9.9506(\mathrm{SD}=4.66074)$ While the average independence after empowering the elderly group through health education is 13.2716 ( $\mathrm{SD}=4.61523)$. Noting this value it appears that there is an increase in the elderly group towards the independence of the ADL of 3321

Tabel 1. Characteristics of respondents.

\begin{tabular}{ccccc}
\hline Independence & $\mathrm{n}$ & Mean & SD & Sig. \\
\hline Pre and Post & 81 & 13.2716 & 4.61523 & 0.00 \\
\hline
\end{tabular}


Table 2. The mean difference of the value of elderly group empowerment against ADL's patience before and after the intervention of health education in arjuna village Bandung.

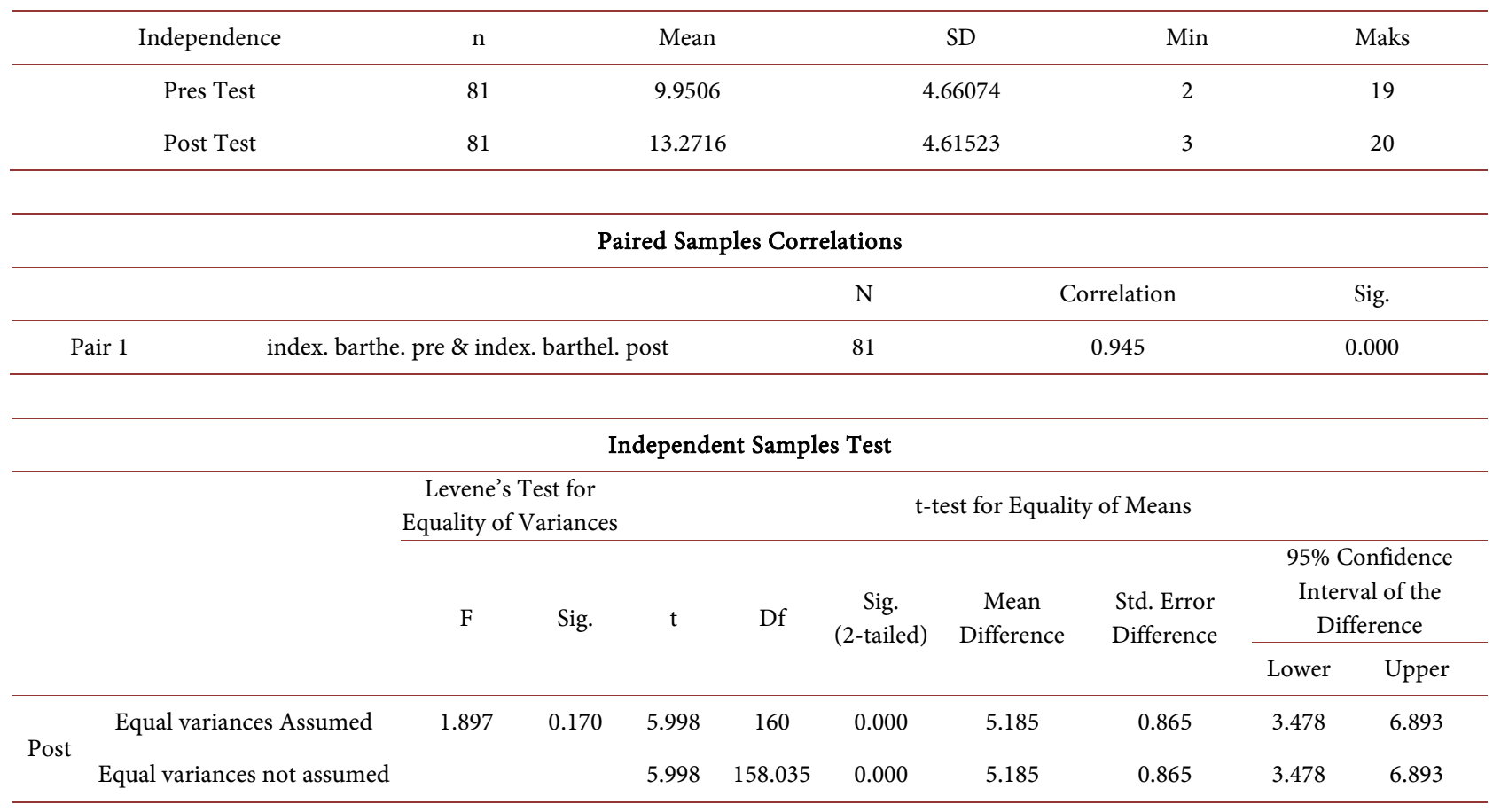

\section{Discussion}

This study compared after empowering the elderly group through health education interventions before and after intervention without any control group. Before the intervention group empowered the elderly through health education, a small proportion of respondents (4.9\%) experienced total dependence, almost all respondents (84.0\%) experienced partial dependence, and a small proportion of respondents (11.1\%) were independent. After empowerment in the elderly group through ADL health education, there were differences, namely a small percentage $(17.3 \%)$ of independent elderly. while almost all elderly are partially dependent $(77.8 \%)$ a small proportion (4.9\%) of total dependence.

\begin{tabular}{cccc}
\hline & $\begin{array}{c}\text { Experienced total } \\
\text { dependence }\end{array}$ & $\begin{array}{c}\text { Experienced partial } \\
\text { dependence }\end{array}$ & independent \\
\hline Before & $4.9 \%$ & $84.0 \%$ & $11.1 \%$ \\
After & $4.9 \%$ & $77.8 \%$ & $17.3 \%$ \\
\hline
\end{tabular}

The results of this study are in accordance with the opinion Maryam et al. that aging is a natural process that cannot be avoided. As the age increases, body functions deteriorate so that the elderly are more easily disturbed by their health, both physical and mental health conditions that experience many setbacks, making the elderly have a tendency to need help in fulfilling their daily needs [18].

The number of eldery with total dependence consists of 4 people. Two of the 
elderly have experienced mild stroke, where all activities in meeting their daily needs require family assistance. While 2 (two) elderly have Parkinson's disease with a state of dependence on drugs, if the reaction on the drug runs out then the elderly cannot independently fulfill their daily lives. Seniors (elderly) with partial dependence, on average need help in washing clothes. This research is in line with the results of the research put forward by Slamet Rohaedi [19] in the Senja Rawi PSTW, the majority of lania had a partial dependence of 15 respondents $(72 \%)$ and a total dependence of 3 people (14\%), because there were some elderly who suffered diseases such as stroke and parkinsonism so that all activities in fulfilling their daily needs require the help of others because this disease makes nerve cells become damaged, nerve cells function to produce important chemicals called dopamine. Dopamine sends a signal to the brain that controls movement so that the disease affects the way it moves. Data found at the time the research was conducted, factors that influence the independence of the elderly, namely age, immobility and easy fall. The first factor that determines the level of independence of the elderly is age. Ediawati's statement that if someone gets older, their physical and mental abilities will slowly decrease [8]. Researchers limit the age of the respondent, which is $60-69$ years according to the age limit determined by the Ministry of Health. The second factor that affects the independence of the elderly is the immobility, immobility itself is the inability of the elderly to actively move. At the time of the study, it was found that 7 elderly people aged 60 - 69 years already had stroke and Parkinson's disease. The three elderly people fall into the category of total dependence because when the results of the study found that all the criteria listed in the Barthel index were carried out by assisting. The elderly with partial dependence or total dependence who cannot carry out activities independently, supported by the family with provided assistive devices such as wheelchairs and crutches. The third factor that affects the independence of the elderly is that it is easy to fall, according to the statement stated by Ediawati if someone increases old, physical and mental abilities will slowly decrease [8]. Declining physical and mental abilities often lead to falls in the elderly, as a result, it will have an impact on decreasing activity in the elderly's independence. As we get older, it will decrease its ability to meet daily needs so that dependence on others increases. Research Results from Rustika, which describe the age of a person will affect their ability to meet their needs. In the research conducted by Suhartini [20] that the factors that influence the independence of the elderly are health conditions, social conditions and economic conditions. The first factor is the health condition that affects the level of independence of the elderly that the elderly need support and motivation as well as assistance from the closest family to visit the health service that has been prepared by the government either at the hospital or in the Puskesmas elderly regularly. By attending a religious event or holding an event with a group of elderly people in the Arjuna village of Bandung such as recreation, the elderly can increase socialization among the elderly.

The third factor is economic condition, all elderly people have economic con- 
ditions that are lacking because they have no financial resources. Most of these elderly people are no longer working and for the elderly who still have families just waiting for help from children or relatives. This research is supported by the theory from Nugroho [21] that the condition of the elderly will cause a decline in the economic field. Retirement will result in lower income, loss of facilities, power, authority and income.

At the time of the study, it was found that independent elderly had a situation where all activities in fulfilling daily life were carried out entirely independently or without the need for assistance. The results of this study are consistent with the research conducted by Suhartini that there is a relationship between health conditions and the independence of the elderly [20]. Theoretically, the elderly who have the highest level of independence are those who are physically and psychologically well-off.

In the elderly with a partial dependence on activities in meeting the daily needs of those who need help, among others, washing clothes and going up and down stairs because almost all elderly people in fulfilling their daily activities need help such as mobilization, climbing stairs, and when walking must be supported by one person. There are some elderly people using walking aids such as sticks/creuk. While for the elderly with total dependence on all activities to fulfill their daily needs, they need help from others.

The effect of empowering the elderly group through health education on the independence of daily living activities or daily activities is an effort or process to foster awareness, willingness, and the ability of the community to recognize, overcome, maintain, protect, and improve their own welfare [16].

The limits of empowerment in the health sector include efforts to foster awareness, willingness, and ability to maintain and improve health so that the purpose of community empowerment is aimed at growing awareness, knowledge and understanding of health for individuals, groups or communities. Knowledge and awareness of ways to maintain and improve health is the beginning of health empowerment. Awareness and knowledge are the initial stages of ability, because the ability is the result of the learning process. Learning itself is a process that begins with the transfer of knowledge from learning resources to the subjects of learning. Therefore the group of elderly who are able to maintain and improve health through the health learning process that begins with the acquisition of health information through health education raises awareness of the importance of health and will motivate the elderly group to fulfill their daily needs independently according to their abilities [22] [23].

\section{Conclusions and Recomendations}

\subsection{Conclusion}

From the results of research on the influence of the empowerment of the elderly group on Activities Daily Living (ADL) independence at Posbindu Arjuna Village, Bandung, it can be concluded as follows: The level of Independence of the 
Elderly (60 - 69 years) in fulfilling the ADL in the Arjuna Village of Bandung found that almost all respondents 63 people (77.8\%) had a degree of dependence in part in fulfilling their daily needs. The effect of empowering the elderly (elderly) group through more effective health education can influence the level of independence by providing a guidebook (module) which is equipped with interesting pictures about the procedures for fulfilling the needs of daily activities, finished providing educational guidebooks finished by providing educational guidebooks. The guidebook is given to the elderly so that so that it affects the elderly memory in a longer period of time.

\subsection{Recommendations}

The results of this study were suggested to public health nurses to be applied (applied) at Posbindu in increasing the independence of the elderly group in their daily activities (Activities Daily Living).

\section{Conflicts of Interest}

The authors declare no conflicts of interest regarding the publication of this paper.

\section{References}

[1] Mickey, S. and Gauntlett, B.P. (2007) Gerontological Nursing: Promoting Successful Aging with Older Adults. FA. Davis Company, Philadelphia, PA.

[2] Supardan, D.I. (2013) Pemberdayaan Masyarakat Bidang Kesehatan. http://doktergigi-semarang.blogspot.com/2013/06/pemberdayaan-masyarakat-bida $\underline{\text { ng-kesehatan.html }}$

[3] Program Suara Pena Himpunan Psikologi Indonesia (HIMPSI) (2017) Mendukung Pemberdayaan Tiga Generasi, Yaitu Sesama Generasi Lanjut Usia, Diakses. http://himpsi.or.id

[4] Indriana, Y. (2012) Gerontologidan Progeria. Pustaka Pelajar, Yogyakarta.

[5] Noorkasiani, T. (2009) Kesehatan Usia Lanjut Dengan Pendekatan Asuhan Keperawatan. Salemba Medika, Jakarta.

[6] Brunner and Suddart (2001) Buku Ajar Keperawatan Medikal Bedah. EGC, Jakarta.

[7] Sugiarto, A. (2005) Penilaian Keseimbangan Dengan Aktivitas Kehidupan Sehari-Hari Pada Lansia D Panti Werdha Pelkris Elim Semarang Dengan Menggunakan Berg Balance Scale Dan Indeks Barthel. UNDIP diakses dari, Semarang. https://www.scribd.com/document/323230235/Activity-of-Daily-Living

[8] Ediawati, E. (2013) Pedoman Pembinaan Kesehatan Usia Lanjut Bagi Petugas Kesehatan. Depkes, Jakarta.

[9] Depkes, R.I. (2010) Pedoman Pembinaan Kesehatan Usia Lanjut Bagi Petugas Kesehatan. Jakarta.

[10] Yulian (2009) Perbedaan Antara Tingkat Kemandirian Lasia Yang Ada di Keluarga di Desa Temoroso Dengan Lansia Yang Ada di Panti Pucang Gading. Semarang, Surakarta.

[11] Dewi, S.R. and Ners, S.K. (2013) Buku Ajar Keperawatan Gerontik. Nuha Medika, Yogyakarta. 
[12] Hidayat, A.A. (2011) Metodologi Penelitian Keperawatandan Teknik Analisa Data. Salemba Medika, Jakarta.

[13] Ariani, A.P. (2014) Aplikasi Metodologi Penelitian Kebidanandan Kesehatan Reproduksi. Nuha Medika, Yogyakarta.

[14] Aimul, A. (2014) Metode Penelitian Keperawatandan Teknik Analisis Data. Medika, Salemba Yogyakarta.

[15] Faisaldo, C. (2014) Keperawatan Komunitas Dengan Pendekatan Praktik. Nuha Medika, Yogyakarta.

[16] Notoatmojo (2007) Promosi Kesehatan dan Ilmu Perilaku. PT Rineka Cipta, Jakarta.

[17] Notoatmojo (2005) Metodologi Penelitian Keperawatan. Jakarta.

[18] Maryam, S., Ekasari, M.F. and Rosidawati (2009) Mengenal Usia Lanjut Dan Perawatan. Salemba Medika, Jakarta.

[19] Rohaedi, S., Putri, S.T. and Karimah, A.D. (2016) Tingkat Kemandirian Lansia dalam Activities Daily Living Di Panti Sosial Tresna Werdha Senja Rawi. Fakultas Keperawatan Universitas Pendidikan Indonesia, Bandung.

[20] Suhartini (2009) Pengaruh Faktor-Faktor Kondisi Kesehatan, Kondisi Ekonomi Dan Kondisi Sosial Terhadap Kemandirian Orang Lanjut Usia, CV Pustaka Setia, Bandung.

[21] Nugroho, W. (2008) Gerontik \& Geriatrik. Edisi 3, EGC, Jakarta.

[22] Marthuranath, P.S., George, A., Cherian, P.J., Mathew, R. and Sarma, P.S. (2005) Instrumental Activities of Daily Living Scale for Dementia Screening in Elderly People. International Psyhogeriatrics, 17, 461-474.

[23] Suhartini, R. (2004) Faktor-Faktor Yang Mempengaruhi Kemandirian Orang Lanjut Usia (Studi Kasus di Kelurahan Jombangan) Tahun 2004.

http://www.damandiri.or.id/file/ratnasuhartiniunairbab2.pdf 